\title{
The gross domestic product (GDP) shares of the agriculture sector and the hydrocarbon and mining sector in the countries of South America between 1960 and 2014
}

\author{
Pedro Henrique de Abreu Paiva \\ and Carlos José Caetano Bacha
}

\begin{abstract}
This article analyses the GDP shares of the agriculture sector and the hydrocarbon and mining sector in the South American countries between 1960 and 2014. Although the share of the agriculture sector has been trending downward in South America, common features can be observed in three subgroups of countries. The first comprises the founding members of MERCOSUR, where agricultural and agro-industrial trade was in surplus and the share of the agriculture sector rose back up between 2002 and 2007. The second subgroup are the Andean countries, where the agriculture sector share of GDP declined from 1960 onward while that of hydrocarbon and mining production increased, especially during the 2000s. The third subgroup consists of Guyana and Suriname, where the historical series of the agriculture sector share of GDP takes the form of an inverted $U$.
\end{abstract}

\section{Keywords}

Agriculture, mining, hydrocarbons, industrial sector, industrial production, gross domestic product, agricultural statistics, industrial statistics, South America, MERCOSUR, Andean region, Guyana, Suriname

JEL classification

$$
\text { 013, O57, Q10 }
$$

Authors

Pedro Henrique de Abreu Paiva holds a master's degree in applied economics from the University of São Paulo and is a planning analyst at the Intermunicipal Cooperation Institution of Paraopeba Media (ICISMEP), Brazil. Email: pedroabreupaiva@gmail.com.

Carlos José Caetano Bacha is a full professor with the Department of Economics, Administration and Sociology of the Luiz de Queiroz Higher School of Agriculture at the University of São Paulo, Brazil. Email: carlosbacha@usp.br. 


\section{Introduction}

The theory of comparative advantage postulates that countries should devote their productive resources (land, labour and capital) to production and service activities in which they have comparative cost advantages relative to other countries. This idea is associated with the fact that foreign investors will decide what and where to produce and where to consume as their interests dictate. These two factors (comparative advantages and the role of foreign capital) determine an international division of labour that largely explains the production structure of the South American countries and the predominance in recent years of agricultural, hydrocarbon and mining activities in this production structure.

Between the sixteenth and nineteenth centuries, the countries of South America were exploited as Spanish and Portuguese colonies, whose main purpose was to supply foreign markets with agricultural and mining products. The role imposed on these colonies limited the development of industrial activity there, turning them into sellers of raw materials and buyers of industrialized products originating in the metropolises of the day (Baer, 2008; Furtado, 1989). This was clearly the international division of labour that existed at that time.

As independent countries, during the second half of the nineteenth century and the first half of the twentieth, the South American countries continued to pursue mining and agriculture as their main activities. In addition to selling these products on foreign markets, they allocated a portion to meeting the increased domestic demand resulting from incipient agro-industrialization. However, these activities were conducted directly or indirectly by foreign capital, primarily of British origin. The dynamism of production was determined by transnational mine-owning companies which also controlled international trade in both agricultural and mining products. This remains the situation to this day.

Between 1950 and 1970, the ideas of the Economic Commission for Latin America and the Caribbean (ECLAC) led South American countries to stimulate their industries. However, most of these stimuli were concentrated on natural resources and agricultural products. Those years were characterized by the implementation of protectionist policies that led to the creation of State monopolies in mining and hydrocarbon exploitation and limited the access of foreign capital, as in the case of Petrobras in Brazil (Baer, 2008). Even so, the role of transnational corporations as the main purchasers of these products was maintained.

According to Silva, Gómez and Castañeda (2012), the neoliberal model began to be adopted in most Latin American countries in the 1990s. In several of them (such as Brazil, Chile, Colombia and Peru), laws were relaxed to allow for increased participation by foreign capital in the direct exploitation of natural resources, and the bulk of these raw materials continued to be exported (Lagos and Peters, 2010). Since then, in addition to existing European and United States investors, new companies financed by capital from other countries interested in exploiting natural resources and carrying out agricultural production in South America, including China, have emerged (llyásova and Sérbinov, 2015). The intention behind this new investment is to receive raw materials in return for the financing provided. According to llyásova and Sérbinov (2015, p. 1), the funding received by the Bolivarian Republic of Venezuela from China since 2007 to develop its oil industry is being paid back in barrels of oil. In the case of Brazil, some lending to the agriculture sector is being channelled through foreign companies that grant loans in the form of inputs in exchange for the agricultural products to be exported (Bacha, 2012).

The 2000s have been characterized as a new, post-neoliberal phase. Foreign capital was invested in South America once again, both to produce raw materials, primarily for export, and to improve infrastructure to make these exports viable. A substantial proportion of these countries' GDP and exports continue to be based on primary commodities. According to data from Belloni and Wainer (2014, p. 106), these accounted for at least 68.8\% of Argentina's exports from 2001 to 2011, while 
the proportions for the Bolivarian Republic of Venezuela, Brazil, Chile, Colombia, Ecuador, Paraguay, Peru, the Plurinational State of Bolivia and Uruguay were 83.7\%, 44.9\%, 80.5\%, 69\%, 91.8\%, 93.1\%, $70.5 \%$ and $79.4 \%$, respectively.

While Chile, Peru and Colombia opted to allow in more foreign capital for the exploitation of natural resources, which were previously in the hands of the State, Brazil, Argentina and Uruguay opted for State ownership but allowed foreign investment in agriculture and granted concessions for the exploitation of hydrocarbons and mining products. The Plurinational State of Bolivia, the Bolivarian Republic of Venezuela and Ecuador tended at times to restrict but not prohibit foreign investment in natural resource exploitation and agriculture. Although these three groups of countries can be differentiated by the scope allowed to foreign investors to participate in the exploitation of raw materials, such exploitation has not yet significantly altered the living conditions of South American populations (Belloni and Wainer, 2014).

Some studies argue that in the period from 2002 to 2008 (during the commodity price boom), South American countries suffered from Dutch disease, a situation in which revenues from raw material exports strengthen local currencies and stimulate imports of industrialized products (Bresser-Pereira and Marconi, 2008, for Brazil). Other authors, however, maintain that this did not occur (Puyana and Constantino, 2013, for Argentina).

It is important to point out that economies based on hydrocarbons and mining could have sustainability problems in future. Not only does the depletion of non-renewable natural resources jeopardize the future of these economies, but considerable environmental damage is being caused by the pollution of rivers and other water sources. Although agriculture also poses environmental challenges, its effects are less than those of mining and it plays an important role in food security.

While the present article will not focus on these topics, it will attempt to show the evolution of agricultural, mining and hydrocarbon activities, highlighting their different trajectories in the countries of South America. It will also argue that the allocation of production factors can give an idea of the differences in the dynamism of these activities in each of the countries. However, the main focus will be on the evolution of the agriculture sector, since although its GDP share has been in continuous decline in the South American countries, it is important to analyse how the patterns of this reduction vary between the different countries.

Specifically, the objective of this article is to analyse the evolution of the agriculture sector share of GDP in the South American countries and compare it with the share of mining and hydrocarbons there. It is expected that differences may be observed in the trajectory of these sectors' GDP shares between 1960 and 2014. Within the historical series analysed, special attention will be paid to the 2000s, since many countries in the region benefited greatly from the mining and agricultural commodity price boom during that period.

Agriculture competes with mining and hydrocarbon exploitation for land, infrastructure, capital investment and public policy attention. Even when an area may be better suited to mining than agriculture (such as Chile's arid north or rocky areas of Peru), State infrastructure investments in those areas divert possible resources that could be used to support other activities elsewhere (such as agriculture). There are also areas that can initially be used for mining and agriculture at the same time, but it is very likely that one of these activities will eventually expel the other. According to Lagos and Peters (2010, p. 3): "In Argentina, for example, mining was important in the mountainous provinces of Mendoza, San Juan, La Rioja, Catamarca, Salta, Jujuy and Neuquén. By the end of the nineteenth century, mining had already lost momentum in the face of the growing importance of agriculture and cattle ranching. Recently, in the last decade of the twentieth century, the establishment of a new legal structure facilitated substantial mining investment, leading to the emergence of mines such as Bajo de la Alumbrera (copper and gold), Cerro Vanguardia and Farallón Negro (gold and silver), Martha (silver), Salar del Hombre Muerto 
(lithium), Andacollo and Veladero (gold) and San José (gold, silver and copper). The tension between agriculture and mining has not diminished, however, and in provinces such as Mendoza, for example, special laws have been drafted in the last decade to make mining more difficult." The same authors (Lagos and Peters, 2010, p. 5) cite the case of the area around Lima, where mining once coexisted with small-scale farming. As time went by, the latter gradually disappeared and the small farmers became the waged workforce needed to sustain mining expansion.

\section{Literature review}

The literature includes a number of studies on the importance of agriculture in the GDP of the South American countries. ${ }^{1}$ Some of the studies analyse the countries separately, others together. There is also an extensive literature on the role of oil production and mining in the GDP of the South American countries. However, no document has attempted to jointly analyse these sectors' contribution to GDP or to compare them across the countries of the region.

In the first place, in view of the diversity of the territories of South America, this section divides the countries of the region into three blocs: those of the Andean Region, the Guianas ${ }^{2}$ and the founding members of MERCOSUR. The countries of the Andean Region are: the Bolivarian Republic of Venezuela, Chile, Colombia, Ecuador, Peru and the Plurinational State of Bolivia. These are traversed by the Andes mountain range, which has enabled them to engage in mining and agriculture since Spanish colonial times. Farming is carried out mainly on plateaus and hillsides and in piedmont areas, but also on low-lying plains. The mining and hydrocarbon industries have attracted new multinational companies since the 1990s, particularly from China. The Guianas occupy what is still a little explored area of tableland, comprising two independent countries: Guyana and Suriname. Lastly, the founding members of MERCOSUR (Argentina, Brazil, Paraguay and Uruguay) share the plains watered by the system of rivers making up the River Plate basin, in which crop (mainly grain) production and cattle ranching are carried on extensively. Argentina and Brazil are the largest countries in MERCOSUR, and their vast territories serve for both agriculture and mining.

Among the Andean countries, the Bolivarian Republic of Venezuela is a particularly large producer of oil, this having been the leading sector in the Venezuelan economy since the 1920s. The country's oil exports were worth $40.7 \%$ of GDP in 2006 and represented almost $90 \%$ of the total that year (Souza, 2008). It is important to mention that few studies have been carried out on Venezuelan agriculture. One of these few is Morales (2002), which analyses maize, wheat and milk imports in the Bolivarian Republic of Venezuela.

One of the Latin American countries where the agriculture sector's share of GDP has fallen in recent decades is Colombia, with a decline from 20\% in 1970 to $7.7 \%$ in 2010 (Fernández, Piñeros and Estrada, 2011; Romero, 2011). According to Rudas and Espitia (2013), mining and hydrocarbons accounted for about 7\% of Colombian GDP in 2012.

As in the Bolivarian Republic of Venezuela, oil activity also accounts for a considerable proportion of the economy in Ecuador. Mateo and García (2014) show that oil is the leading sector in the Ecuadorian economy, since in 2012 it represented more than 12\% of GDP and was one of the main export products (58\%). Agriculture, conversely, is much less important to the Ecuadorian economy. According to Tandazo (2012), agriculture, including fisheries, accounted for about 10\% of Ecuador's gross value added (GVA) that year.

\footnotetext{
1 In this article, the term "agriculture" covers both crop and livestock production.

2 For the purposes of this analysis, the Guianas comprise two independent countries, Guyana and Suriname, and do not include French Guiana.
} 
In Peru, according to the Food and Agriculture Organization of the United Nations (FAO/CAF, 2006), both profits and competitiveness in agriculture are low. The emphasis of rural activities in the country is also on mining, since Peru is the world's leading producer of silver, with a $6.5 \%$ share of the global total in 2006. That same year, Peru was also the world's third-largest producer of copper and zinc, the fourth-largest producer of lead and the fifth-largest producer of gold (Dammert and Molinelli, 2007). Landa (2017) evaluates the impact of copper production on Peru's educational, health and road infrastructure between 2004 and 2013 and shows that this infrastructure improved more in extraction zones than elsewhere. However, the improvement was far below potential.

In the case of the Plurinational State of Bolivia, according to Urioste (2009), the GDP share of agriculture was 13\% in 2008, the lowest rate since 1983. Montenegro and Guzmán (1999) found that the agriculture sector represented 15\% of Bolivian GDP in 1995 and 1997, the lowest value observed in the 1970 to 1997 time series. On the other hand, minerals accounted for some $20 \%$ of the country's total exports in the period from 2005 to 2008, surpassed only by natural gas, exports of which increased substantially from 2003 onward, as Urioste (2009) points out.

The main product exported by the Chilean mining industry is copper, with exports worth almost US\$ 18 billion in 2004 (Guajardo, 2007). The agriculture sector plays a secondary role in Chile's GDP, for although there has been a steady increase in the real value of production since 1962, it only represented 3.09\% of GDP in 2007 (INE-Chile, 2009).

Guyana and Suriname are located in the north of South America and gained independence from Britain and the Netherlands, respectively, only in the 1970s. Although their economies are embryonic and infrastructure is very poor, Guyana and Suriname have great productive potential in the energy and mining sectors (Visentini, 2010). Guyana's economy continues to depend on the export of a few unprocessed commodities, such as gold and rice (Gold and Atoyan, 2007). In Suriname, agriculture remains unrepresentative, with a 9\% share of GDP in 1992-1995 (Boye and Ramautarsing, 1997). According to Visentini (2010), there is scope for greater exploration of gold deposits in Suriname and, consequently, greater production of oil and gas.

In the southern part of South America are the River Plate countries, namely Argentina, Paraguay and Uruguay. The River Plate basin is very large and is formed by three rivers (the Paraná, the Paraguay and the Uruguay) that originate in Brazil. With very fertile soils, it is a region well suited to agriculture (Zarilli, 2013).

Regarding the importance of agriculture to the Argentine economy, we may cite, for example, Reca (2006), which analyses its development from 1875 to 2005. According to that study, Argentina's agriculture sector grew considerably during the period and the country became one of the world's leading exporters of grains, beef, wool and vegetable oils. However, there have been some fluctuations in recent years. Although agricultural value added decreased from 1999 to 2002 (because of the country's economic crisis in those years), between 2003 and 2005 the figure grew at an average annual rate of 5\%, a level similar to that in the period 1875-1928, when the Argentine economy was dominated by cattle ranching. The country is one of the world's leading meat producers, and output of chicken and pork has increased by more than that of beef (Reca and Lema, 2016). According to Lence (2010), almost half of Argentina's exports between 2000 and 2007 were of agricultural products, which represented $8.4 \%$ of world agricultural production in the period. Puyana and Constantino (2013) analyse this expansion of agriculture and the dependence of Argentina's trade balance on agricultural commodities (especially soy), but find no evidence of Dutch disease in Argentina.

Agriculture also represents a large share of GDP and the trade balance in Paraguay and Uruguay, accounting for some 24\% of Paraguayan GDP in the period 2000-2010 (Servín, 2011). According to Cresta and others (2014), agriculture represented 24.6\% of Paraguay's GDP in 2013 and an average of 
27.8\% of its exports between 2000 and 2013. In Uruguay, data from INE-Uruguay (2009) indicate that agriculture represented 9.9\% of GDP in 2010. Oyhantçabal and Sanguinetti (2017) analyse changes in Uruguayan agriculture between 2000 and 2015, assessing income distribution and pointing out that landowners have captured a large share of revenues.

Brazil is geographically the largest South American country and is currently one of the world's largest producers and exporters of agricultural products. In a study covering the period 1955-1996, Bacha and Rocha (1998) found a decrease in the agriculture sector's share of Brazilian GDP, from $23.5 \%$ in 1955 to $7.7 \%$ in 1989. Drawing on another set of data from Brazil's national accounts, Bacha (2012) analysed the period 1947-2010 and observed an increase in the contribution of agriculture to Brazil's GDP between 1998 and 2003. This was due to three main factors: (i) an increase in agricultural productivity combined with a decrease in industrial productivity; (ii) an improvement in the ratio of agricultural to industrial prices; (iii) an improvement in the ratio between prices charged and prices paid by ranchers and farmers. However, the years 2005 and 2006 were characterized by a decline in the GDP share of agriculture in Brazil, largely due to the strong appreciation of the real against the dollar and falling international agricultural commodity prices. This share recovered between 2007 and 2010.

In the 1990s, with increased economic liberalization, Brazil consolidated its position as the leading producer and exporter of several agricultural products, such as orange juice, sugar and chicken meat, in addition to the products of the soybean production chain (Jales, 2005). Bacha (2011) points out that rising agricultural output and commodity prices led to a large increase in Brazilian agricultural production and exports from 1998, which in turn drove a recovery in the country's agricultural GDP. The contribution of the agriculture sector to Brazil's GDP is also analysed by Brugnaro and Bacha (2009). Drawing on data for the period 1986-2004, the authors find that, despite the historical trend towards a declining share for agriculture in Brazil's GDP, that trajectory was reversed between 1993 and 2004.

Lastly, as mentioned earlier, while some studies in the literature focus on Latin America, other works analyse certain countries in the region individually. According to Pardey, Wood and Hertford (2009), there is a positive correlation between total GDP growth and agricultural GDP growth in Latin America during the period 1961-2002, especially in countries such as Belize, Brazil, Mexico and Paraguay. In spite of this, the period was characterized by a decline in the share of agriculture in the total GDP of the Latin American countries.

As regards trade, Latin America's agricultural trade surplus is due to the trade performance of a few countries, especially Argentina and Brazil, where the largest surpluses were recorded in 1999. In contrast, the Bolivarian Republic of Venezuela, Chile and Suriname, among others, have negative agricultural trade balances (Acosta, 2006). Valdés and Foster (2011) also point out the importance of agriculture in these countries' trade balances between 2000 and 2002. According to these authors, of the countries analysed, only Argentina, Uruguay, Brazil, Paraguay and the Plurinational State of Bolivia were net exporters of food, especially the first four.

Overall, the literature analysed has lost topicality, since much has changed over the last 10 years in the countries dealt with by the studies cited. Furthermore, the literature was not found to contain any analysis of compensation in the use of production factors (especially land use) between agriculture and the mining and hydrocarbon extraction industry in the South American countries.

The following section focuses on this compensation, analysing the period from 1960 to 2014, so that it covers a longer time span than the literature analysed. 


\section{Results}

This document is based on a set of data from the World Bank $(n / d)$ and the Food and Agriculture Organization of the United Nations (FAO). The two agencies provide similar information for South American countries on: (i) the use of production factors (such as land, capital and labour); (ii) the gross value and value added of agricultural production; and (iii) macroeconomic indicators, such as the trade balance and the GDP shares of agriculture and of hydrocarbon production and mining. These data are organized into tables and charts. Some data series are available from 1960 and others from 1990. The availability of a data series from 1960 facilitates comparison between the periods before and after the opening up of the South American economies in the 1990s.

\section{Land availability, fixed capital investment and agricultural labour productivity in the South American countries}

The ratio of farmland to total available land generally expanded in all the South American countries between 1961 and 2013 (see table 1). However, the three groups mentioned earlier (MERCOSUR, the Andean countries and the Guianas) have different patterns of land use.

Table 1

South America (12 countries): agricultural land as a proportion of total available land, 1961-2013

(Percentages, annual averages over each five-year period)

\begin{tabular}{lcccccc}
\hline \multirow{2}{*}{ Country } & \multicolumn{7}{c}{ Years } \\
\cline { 2 - 7 } & $1961-1964$ & $1970-1974$ & $1980-1984$ & $1990-1994$ & $2000-2004$ & $2010-2013^{\mathrm{a}}$ \\
\hline Argentina & 49.55 & 47.15 & 46.91 & 46.68 & 47.58 & 54.28 \\
\hline Brazil & 18.96 & 24.26 & 27.21 & 29.53 & 31.86 & 33.00 \\
\hline Paraguay & 26.65 & 29.37 & 35.13 & 42.83 & 49.88 & 53.93 \\
\hline Uruguay & 92.60 & 87.99 & 85.83 & 85.28 & 85.25 & 82.21 \\
\hline Bolivia (Plurinational State of) & 27.62 & 28.70 & 31.51 & 33.17 & 34.13 & 34.54 \\
\hline Chile & 18.35 & 21.02 & 22.39 & 21.03 & 20.76 & 21.21 \\
\hline Colombia & 37.05 & 40.26 & 40.85 & 40.51 & 38.33 & 38.68 \\
\hline Ecuador & 17.03 & 18.02 & 24.96 & 28.77 & 30.70 & 30.06 \\
\hline Peru & 13.51 & 14.18 & 14.66 & 17.08 & 17.93 & 18.90 \\
\hline Venezuela (Bolivarian Republic of) & 21.92 & 22.78 & 24.01 & 24.61 & 24.48 & 24.49 \\
\hline Guyana & 6.91 & 6.98 & 8.74 & 8.81 & 8.68 & 8.52 \\
\hline Suriname & 0.27 & 0.34 & 0.47 & 0.57 & 0.52 & 0.50 \\
\hline
\end{tabular}

Source: Prepared by the authors, on the basis of data from World Bank, "World Development Indicators (WDI)" (n/d) [online database] http://databank.worldbank.org/data/reports.aspx?source=world-development-indicators.

a Data for 2014 are not available in the database used and a four-year average is taken.

Uruguay is the South American country that devotes the highest proportion of its total land area to agriculture. In the period under review, at least $82 \%$ of Uruguayan territory was given over to agriculture. In Paraguay, meanwhile, there have been large changes in land use. Between 1961-1964 and 2010-2013, the proportion of land used for agriculture doubled from an average of $26.65 \%$ to an average of 53.93\%. Uruguay and Paraguay, like Argentina and Brazil, have climatic and geographical 
conditions favourable to agriculture, particularly grain production and cattle ranching. At least half of Argentina's territory has been devoted to these activities since the mid-2000s, while they occupy a third of Brazil's.

Of the Andean countries, the Plurinational State of Bolivia and Colombia devote more than 30\% of their territory to agriculture, while in Chile and Peru the proportion is less than $23 \%$. Although Guyana and Suriname have increased the area devoted to agriculture, it represents no more than $9 \%$ and $1 \%$ of their territories, respectively (see table 1).

The data in table 2 show that most of the countries studied registered an increase in the capital employed in agriculture between 1990 and 2009, the exceptions being Argentina, Ecuador, Guyana and Suriname. This may indicate that most South American countries have invested more capital in the agriculture sector, undoubtedly accompanied by technological improvements.

Table 2

South America (12 countries): value of agricultural capital, 1990-2009

(Millions of 2005 dollars, annual averages over each five-year period)

\begin{tabular}{lrrrrr}
\hline \multirow{2}{*}{ Country } & \multicolumn{2}{c}{ Years } & \multicolumn{2}{c}{$\begin{array}{c}\text { Rate of growth } \\
\text { between (D) and (A) } \\
\text { (percentages) }\end{array}$} \\
\cline { 2 - 5 } Argentina & $\begin{array}{c}1990-1994 \\
\text { (A) }\end{array}$ & $\begin{array}{c}1995-1999 \\
\text { (B) }\end{array}$ & $\begin{array}{c}2000-2004 \\
\text { (C) }\end{array}$ & $\begin{array}{c}\text { 2005-2009a } \\
\text { (D) }\end{array}$ & -2.3 \\
\hline Brazil & 80542.25 & 76518.69 & 76395.35 & 78691.86 & 19.6 \\
\hline Paraguay & 178040.60 & 184457.10 & 200059.20 & 212934.90 & 21.8 \\
\hline Uruguay & 6782.61 & 7665.08 & 7706.85 & 8259.37 & 9.4 \\
\hline Bolivia (Plurinational State of) & 22890.60 & 23290.34 & 23258.09 & 25045.91 & 40.2 \\
\hline Chile & 6470.62 & 7189.41 & 8157.64 & 9072.33 & 12.6 \\
\hline Colombia & 20305.29 & 22627.82 & 22995.87 & 22872.66 & 3.6 \\
\hline Ecuador & 97536.07 & 100675.30 & 97900.85 & 101015.10 & -3.8 \\
\hline Peru & 20038.09 & 20977.49 & 19689.86 & 19279.80 & 18.3 \\
\hline Venezuela (Bolivarian Republic 0f) & 19824.48 & 21258.93 & 22601.76 & 23442.91 & 11.5 \\
\hline Guyana & 26399.50 & 27168.88 & 28563.28 & 29442.64 & -6.0 \\
\hline Suriname & 1112.20 & 1078.95 & 1055.91 & 1045.46 & -5.2 \\
\hline
\end{tabular}

Source: Prepared by the authors, on the basis of data from the Food and Agriculture Organization of the United Nations (FAO), "FAOSTAT" (n/d) [online database] http://faostat3.fao.org/.

Note: Forestry and fisheries are not taken into account in this calculation. The physical assets it includes are those used in production processes covering land use, irrigation works, structures, machinery and animals.

a Data for 2008 and 2009 are not available in FAOSTAT and a three-year average is taken.

Although agriculture is prominent in Argentina, its share of the country's GDP has declined in recent decades. Agricultural value added increased more quickly in the period after 2003, as Reca (2006) points out. Thus, the decline in the value of fixed capital stocks in Argentine agriculture in the 1990s and their increase in the following decade may be related to the performance of the Argentine economy in past decades. Ecuador, Guyana and Suriname, unlike Argentina, are not strongly oriented towards agriculture. These three countries have registered an increasing use of land in activities other than agriculture, a trend that in turn is related to a reduction in fixed capital stocks in that sector.

Despite the heterogeneous evolution of gross fixed capital formation, agricultural gross value added per worker (an indicator of agricultural productivity, see table 3) increased significantly over time in all the South American countries. On average, the founding countries of MERCOSUR experienced higher growth than the other countries studied. Two key factors explaining these differences are the global increase in agricultural commodity prices and the increased use of skilled labour in agriculture, especially in the 2000s and 2010s. 
Table 3

South America (11 countries): gross value added per worker in the agriculture sector, 1990-2014 (2005 dollars, annual averages over each five-year period)

\begin{tabular}{|c|c|c|c|c|c|c|}
\hline \multirow[b]{2}{*}{ Country } & \multicolumn{5}{|c|}{ Years } & \multirow{2}{*}{$\begin{array}{l}\text { Rate of growth } \\
\text { between }(\mathrm{E}) \text { and }(\mathrm{A}) \\
\text { (percentages) }\end{array}$} \\
\hline & $\begin{array}{c}1990-1994 \\
\text { (A) }\end{array}$ & $\begin{array}{c}1995-1999 \\
\text { (B) }\end{array}$ & $\begin{array}{l}2000-2004 \\
\text { (C) }\end{array}$ & $\begin{array}{l}2005-2009 \\
\text { (D) }\end{array}$ & $\begin{array}{l}2010-2014 \\
\text { (E) }\end{array}$ & \\
\hline Argentina & 7670.36 & 9203.27 & 9918.16 & 11638.02 & 12293.46 & 60.3 \\
\hline Brazil & 1741.92 & 2157.83 & 2859.53 & 3753.83 & 4959.65 & 184.7 \\
\hline Paraguay & $1678.44^{\mathrm{a}}$ & 1846.01 & 1910.79 & 2207.43 & 2807.21 & 67.3 \\
\hline Uruguay & 5852.37 & 7310.11 & 7201.98 & 8215.57 & 9410.55 & 60.8 \\
\hline Bolivia (Plurinational State of) & 621.96 & 629.69 & 617.01 & 639.41 & 643.99 & 3.5 \\
\hline Chile & 3303.21 & 3615.41 & 4717.61 & 5697.36 & 6371.00 & 92.9 \\
\hline Colombia & 3509.61 & 2959.87 & 2889.40 & 3308.13 & 3657.16 & 4.2 \\
\hline Ecuador & 2086.87 & 2405.62 & 2792.12 & 3398.61 & 4000.32 & 91.7 \\
\hline Peru & 1029.24 & 1230.21 & 1401.20 & 1625.90 & $1848.03^{c}$ & 79.6 \\
\hline Guyana & 3248.93 & 4473.55 & 4781.87 & 4291.03 & $4761.84^{b}$ & 46.6 \\
\hline Suriname & 3172.20 & 2753.69 & 2955.24 & 3009.33 & $3848.04^{b}$ & 21.3 \\
\hline
\end{tabular}

Source: Prepared by the authors, on the basis of data from World Bank, "World Development Indicators (WDI)" (n/d) [online database] http://databank.worldbank.org/data/reports.aspx?source=world-development-indicators.

a Data for 1990 are not available in the database used and a four-year average is taken.

b Data for 2014 are not available in the database used and a four-year average is taken.

c Data for 2013 and 2014 are not available in the database used and a three-year average is taken.

\section{Agricultural output and trade balances in the countries of South America}

Between 1990 and 2013, the value of agricultural production increased in all the South American countries examined except Suriname (see table 4). In the case of crop production, the increase was greater in the founding countries of MERCOSUR than in the Andean countries, while the reverse was true of livestock production. The growth in the value of both agriculture and livestock production was due to the expansion of farmland, the growth of fixed capital and rising labour productivity, as shown in tables 1 to 3, respectively. The greater abundance of flatlands in the MERCOSUR countries as compared to the Andean ones gave the former a comparative advantage that allowed them to increase grain production more rapidly. In some Andean countries, many rocky areas are better suited to livestock than to crops.

Table 4

South America (11 countries): average annual crop and livestock production by value, 1990-2014 (Millions of averaged 2004 to 2006 dollars, annual averages over each five-year period)

\begin{tabular}{|c|c|c|c|c|c|c|}
\hline \multirow[b]{2}{*}{ Country } & \multicolumn{5}{|c|}{ Years } & \multirow{2}{*}{$\begin{array}{l}\text { Rate of growth } \\
\text { between (E) and (A } \\
\text { (percentages) }\end{array}$} \\
\hline & $\begin{array}{c}1990-1994 \\
\text { (A) }\end{array}$ & $\begin{array}{c}1995-1999 \\
\text { (B) }\end{array}$ & $\begin{array}{c}2000-2004 \\
\text { (C) }\end{array}$ & $\begin{array}{l}2005-2009 \\
\text { (D) }\end{array}$ & $\begin{array}{l}2010-2013^{a} \\
\text { (E) }\end{array}$ & \\
\hline \multicolumn{7}{|l|}{ Crop production } \\
\hline Argentina & 8874.81 & 11373.72 & 13651.46 & 16209.11 & 18539.29 & 108.9 \\
\hline Brazil & 25035.17 & 28377.74 & 35894.12 & 44052.61 & 52712.74 & 110.6 \\
\hline Paraguay & 722.51 & 979.77 & 1258.33 & 1678.40 & 2383.56 & 229.9 \\
\hline Uruguay & 495.03 & 672.16 & 655.72 & 955.22 & 1395.96 & 182.0 \\
\hline Bolivia (Plurinational State of) & 622.71 & 810.15 & 970.40 & 1097.04 & 1308.49 & 110.1 \\
\hline Chile & 2196.95 & 2480.69 & 2766.46 & 2835.81 & 3070.25 & 39.8 \\
\hline Colombia & 5501.58 & 5366.71 & 5570.88 & 6048.33 & 5933.28 & 7.8 \\
\hline Ecuador & 1583.48 & 1808.60 & 1835.06 & 1959.33 & 2219.07 & 40.1 \\
\hline Peru & 1373.71 & 2040.93 & 2648.63 & 3165.37 & 3826.75 & 178.6 \\
\hline Guyana & 3.91 & 6.47 & 5.85 & 7.57 & 6.54 & 67.3 \\
\hline Suriname & 96.97 & 84.71 & 71.71 & 79.39 & 94.08 & -3.0 \\
\hline
\end{tabular}


Table 4 (concluded)

\begin{tabular}{|c|c|c|c|c|c|c|}
\hline \multirow[b]{2}{*}{ Country } & \multicolumn{5}{|c|}{ Years } & \multirow{2}{*}{$\begin{array}{l}\text { Rate of growth } \\
\text { between (E) and (A) } \\
\text { (percentages) }\end{array}$} \\
\hline & $\begin{array}{c}1990-1994 \\
\text { (A) }\end{array}$ & $\begin{array}{l}1995-1999 \\
\text { (B) }\end{array}$ & $\begin{array}{c}2000-2004 \\
\text { (C) }\end{array}$ & $\begin{array}{l}2005-2009 \\
\text { (D) }\end{array}$ & $\begin{array}{l}2010-2013^{\mathrm{a}} \\
\text { (E) }\end{array}$ & \\
\hline \multicolumn{7}{|l|}{ Livestock production } \\
\hline Argentina & 1973.98 & 2652.88 & 2593.54 & 3257.18 & 3808.27 & 92.9 \\
\hline Brazil & 14500.07 & 19312.28 & 24662.94 & 30528.29 & 34738.48 & 139.6 \\
\hline Paraguay & 550.54 & 634.27 & 742.11 & 853.53 & 980.12 & 78.0 \\
\hline Uruguay & 1105.10 & 1304.70 & 1202.65 & 1488.01 & 1519.57 & 37.5 \\
\hline Bolivia (Plurinational State of) & 281.28 & 334.53 & 376.09 & 512.23 & 575.43 & 104.6 \\
\hline Chile & 1437.30 & 1842.72 & 2100.24 & 2603.46 & 2816.52 & 96.0 \\
\hline Colombia & 3427.38 & 4002.99 & 4466.68 & 5461.96 & 5926.12 & 72.9 \\
\hline Ecuador & 1077.27 & 1542.32 & 1843.95 & 2183.43 & 2589.97 & 140.4 \\
\hline Peru & 1173.61 & 1483.15 & 1859.20 & 2478.74 & 3194.89 & 172.2 \\
\hline Guyana & 7.89 & 11.67 & 14.03 & 19.60 & 18.93 & 139.9 \\
\hline Suriname & 45.61 & 31.65 & 29.62 & 34.76 & 40.78 & -10.6 \\
\hline
\end{tabular}

Source: Prepared by the authors, on the basis of data from the Food and Agriculture Organization of the United Nations (FAO), "FAOSTAT" (n/d) [online database] http://faostat3.fao.org/.

Notes: Following FAO, these values are calculated by multiplying the physical quantity of gross output by farm gate prices.

a Data for 2014 are not available in FAOSTAT and a four-year average is taken.

It is well known that Brazil and Argentina are, in that order, the largest producers of crops and livestock in South America, owing to the size of their territories and their climatic diversity. However, it is also important to highlight the strong growth of crop production in Uruguay and Paraguay and of livestock production in Ecuador, the Plurinational State of Bolivia, Peru and Guyana. Much of the agricultural output of the South American countries goes to foreign markets. All the South American countries surveyed except Peru and Suriname run trade surpluses in agricultural and agro-industrial products (see table 5).

Table 5

South America (12 countries): agricultural and agro-industrial trade balances, 1990-2014 (Millions of dollars, annual averages over each five-year period)

\begin{tabular}{lrrrrr}
\hline \multirow{2}{*}{ Country } & \multicolumn{5}{c}{ Years } \\
\cline { 2 - 6 } & 1990-1994 & $1995-1999$ & $2000-2004$ & 2005-2009 & \multicolumn{1}{c}{ 2010-2013 } \\
\hline Argentina & 6363.68 & 9652.60 & 11552.21 & 23730.49 & 37329.78 \\
\hline Brazil & 6575.05 & 8749.22 & 15146.18 & 38089.01 & 66825.63 \\
\hline Paraguay & 413.94 & 181.39 & 572.85 & 1794.50 & 3789.57 \\
\hline Uruguay & 515.90 & 751.19 & 784.64 & 2163.76 & 4160.88 \\
\hline Bolivia (Plurinational State of) & 49.10 & 180.44 & 233.04 & 427.60 & 869.54 \\
\hline Chile & 883.35 & 1355.97 & 2112.28 & 3287.58 & 5037.82 \\
\hline Colombia & 1999.20 & 1903.14 & 1305.79 & 2465.39 & 1206.92 \\
\hline Ecuador & 797.19 & 1178.10 & 1144.55 & 1799.00 & 2777.61 \\
\hline Peru & -491.55 & -642.97 & -271.63 & -153.53 & 79.79 \\
\hline Venezuela (Bolivarian Republic 0f) & -810.06 & -1126.56 & -1701.49 & -5378.88 & -8617.49 \\
\hline Guyana & 108.75 & 156.83 & 88.40 & 122.77 & 129.62 \\
\hline Suriname & -20.44 & -58.85 & -68.01 & -125.70 & -148.54 \\
\hline
\end{tabular}

Source: Prepared by the authors, on the basis of data from the Food and Agriculture Organization of the United Nations (FAO), "FAOSTAT" (n/d) [online database] http://faostat3.fao.org/.

a Four-year average.

The founding countries of MERCOSUR have the strongest trade balances. Both production and exports of agricultural and agro-industrial products have increased considerably in this group of countries. In Brazil, for example, average annual agricultural output grew by 110.6\% from 1990-1994 to 2010-2013. At the same time, the average value of the South American giant's annual livestock production increased by $139.6 \%$. As a result, Brazil's trade surplus in these products grew by $916.4 \%$ over the same period. Paraguay, Uruguay and Argentina also recorded substantial growth, with their 
trade surpluses in agricultural and agro-industrial products increasing by $815.5 \%, 706.5 \%$ and $486.6 \%$, respectively. These figures clearly position them as agro-exporting countries.

Acosta (2006) points out that the Bolivarian Republic of Venezuela and Suriname have run agricultural and agro-industrial trade deficits since 1990, a trend that continued in the 2000s (see table 5). Like these two countries, Peru has a poor agricultural and agro-industrial trade balance.

A general review of tables 5 and 6 shows that the countries with the highest agricultural production are also those with the largest agricultural and agro-industrial trade surpluses.

\section{Table 6}

South America (12 countries): gross domestic product (GDP) shares of the agriculture sector and the mining and hydrocarbons sector and gross value added (GVA) of the agriculture sector, 1990-2014

(Percentages and millions of 2004 dollars, annual averages by five-year period)

\begin{tabular}{|c|c|c|c|c|c|c|}
\hline \multirow{2}{*}{ Country } & \multirow{2}{*}{ Indicator } & \multicolumn{5}{|c|}{ Years } \\
\hline & & 1990-1994 & 1995-1999 & 2000-2004 & 2005-2009 & 2010-2014 \\
\hline \multirow[t]{3}{*}{ Argentina } & GDP share of agriculture & 6.37 & 5.61 & 8.16 & 7.68 & 7.59 \\
\hline & Agricultural GVA & 11254.63 & 13577.04 & 14543.08 & 16787.16 & 17174.24 \\
\hline & GDP share of mining and hydrocarbons & 1.50 & 1.40 & 3.84 & 3.79 & 3.43 \\
\hline \multirow{3}{*}{$\begin{array}{l}\text { Bolivia (Plurinational } \\
\text { State of) }\end{array}$} & GDP share of agriculture & 16.66 & 16.06 & 15.18 & 13.69 & $12.91^{\mathrm{a}}$ \\
\hline & Agricultural GVA & 765.24 & 894.69 & 1010.77 & 1181.96 & $1298.41^{\mathrm{a}}$ \\
\hline & GDP share of mining and hydrocarbons & 3.12 & 2.20 & 3.97 & 8.50 & 9.24 \\
\hline \multirow[t]{3}{*}{ Brazil } & GDP share of agriculture & 8.20 & 5.45 & 6.29 & 5.29 & 5.29 \\
\hline & Agricultural GVA & 24596.07 & 29563.82 & 37251.28 & 44503.25 & 51646.47 \\
\hline & GDP share of mining and hydrocarbons & 1.35 & 0.95 & 2.91 & 4.22 & 4.78 \\
\hline \multirow[t]{3}{*}{ Chile } & GDP share of agriculture & 9.45 & 6.71 & 5.31 & 3.87 & 3.37 \\
\hline & Agricultural GVA & 3155.41 & 3513.86 & 4560.25 & 5543.57 & 6094.67 \\
\hline & GDP share of mining and hydrocarbons & 7.46 & 5.90 & 7.31 & 14.98 & 16.58 \\
\hline \multirow[t]{3}{*}{ Colombia } & GDP share of agriculture & 15.98 & 14.21 & 8.96 & 7.87 & 6.77 \\
\hline & Agricultural GVA & 12063.42 & 10317.34 & 10351.11 & 11776.02 & 12720.00 \\
\hline & GDP share of mining and hydrocarbons & 5.00 & 3.48 & 5.17 & 5.75 & 8.49 \\
\hline \multirow[t]{3}{*}{ Ecuador } & GDP share of agriculture & 22.02 & 20.32 & 12.87 & 9.91 & 9.60 \\
\hline & Agricultural GVA & 3911.27 & 4918.57 & 3237.96 & 4969.26 & 7885.81 \\
\hline & GDP share of mining and hydrocarbons & 9.62 & 7.51 & 13.36 & 16.99 & $17.48^{\mathrm{a}}$ \\
\hline \multirow[t]{3}{*}{ Guyana } & GDP share of agriculture & 38.07 & 36.96 & 30.99 & 24.57 & 18.56 \\
\hline & Agricultural GVA & 185.69 & 249.53 & 260.05 & 223.16 & $234.45^{\mathrm{a}}$ \\
\hline & GDP share of mining and hydrocarbons & 8.82 & 4.57 & 3.35 & 5.36 & $12.94^{\mathrm{a}}$ \\
\hline \multirow[t]{3}{*}{ Paraguay } & GDP share of agriculture & $17.57^{\mathrm{a}}$ & 18.18 & 16.83 & 20.47 & $26.34^{\mathrm{a}}$ \\
\hline & Agricultural GVA & $1028.04^{\mathrm{a}}$ & 1250.36 & 1415.09 & 1763.59 & 2385.50 \\
\hline & GDP share of mining and hydrocarbons & 0.00 & 0.00 & 0.00 & 0.00 & $0.00^{\mathrm{a}}$ \\
\hline \multirow[t]{3}{*}{ Peru } & GDP share of agriculture & $9.30^{\mathrm{a}}$ & 9.38 & 8.39 & 7.62 & $7.39^{b}$ \\
\hline & Agricultural GVA & 2980.95 & 3917.06 & 4818.63 & 5877.49 & $6966.64^{\mathrm{a}}$ \\
\hline & GDP share of mining and hydrocarbons & 3.74 & 1.57 & 2.03 & 9.41 & $10.91^{\mathrm{a}}$ \\
\hline \multirow[t]{3}{*}{ Suriname } & GDP share of agriculture & 13.01 & 12.65 & 8.63 & 8.12 & $7.43^{\mathrm{a}}$ \\
\hline & Agricultural GVA & 91.37 & 79.28 & 89.85 & 97.00 & $126.99^{\mathrm{a}}$ \\
\hline & GDP share of mining and hydrocarbons & 20.01 & 8.07 & 11.00 & 12.68 & $25.93^{\mathrm{a}}$ \\
\hline \multirow[t]{3}{*}{ Uruguay } & GDP share of agriculture & 8.36 & 7.82 & 9.24 & 10.34 & $9.49^{c}$ \\
\hline & Agricultural GVA & 1105.86 & 1408.38 & 1361.97 & 1562.28 & 1771.87 \\
\hline & GDP share of mining and hydrocarbons & 0.00 & 0.00 & 0.03 & 0.10 & $0.12^{\mathrm{a}}$ \\
\hline \multirow{3}{*}{$\begin{array}{l}\text { Venezuela (Bolivarian } \\
\text { Republic of) }\end{array}$} & GDP share of agriculture & 5.44 & 5.02 & 4.29 & 4.54 & $5.56^{b}$ \\
\hline & Agricultural GVA & 4105.58 & 4267.59 & 4764.72 & 5595.08 & $5875.18^{a}$ \\
\hline & GDP share of mining and hydrocarbons & 25.79 & 20.24 & 24.96 & 23.12 & $24.94^{\mathrm{a}}$ \\
\hline
\end{tabular}

Source: Prepared by the authors, on the basis of data from World Bank, "World Development Indicators (WDI)" (n/d) [online database] http://databank.worldbank.org/data/reports.aspx?source=world-development-indicators.

a Data for one of the years are not available in the database used and a four-year average is taken.

b Data for 2013 and 2014 are not available in the database used and a three-year average is taken.

c Data for 2012, 2013 and 2014 are not available in the database used and a two-year average is taken. 


\section{The GDP shares of the agriculture sector and the mining and hydrocarbons sector in the South American countries}

Table 6 shows the evolution of the GDP shares of agriculture and of mining and hydrocarbons (the latter two being taken together) in the South American countries from 1990 to 2014. These shares are calculated as annual averages over five-year periods, and the gross value added of the agriculture sector is measured in millions of dollars at constant 2004 prices.

The data suggest that the importance of mining and hydrocarbon exploitation increased during the period under review in all the South American countries surveyed except Paraguay and the Bolivarian Republic of Venezuela. In Paraguay, the data indicate that these sectors make no contribution to GDP. In the Bolivarian Republic of Venezuela, mining and hydrocarbon exploitation (and especially oil production) has been very important since the beginning of the data series, and the fact that its share of GDP changed so little between 1990 and 2014 reflects the rigidity of the country's production structure and its historical dependence on oil. In Chile, Ecuador, Guyana, Peru and Suriname, the GDP share of mining and hydrocarbons also increased. Similarly, and despite the predominance of the agriculture sector, the GDP share of mining and hydrocarbons in Argentina and Brazil likewise rose over the course of the series.

An examination of the data set in table 6 reveals that the importance of mining and hydrocarbon exploitation in the South American economies has increased overall in recent years, even as the GDP share of the agriculture sector has declined sharply in most of the countries. This pattern was expected because the share of value added in the economy contributed by the industrial and service sectors has grown faster than that of the agriculture sector since the mid-twentieth century.

Despite the downward trend in the contribution of agriculture to the GDP of the South American countries, the gross value added of this sector has continued to rise in most of them. In Peru, for example, the average GVA of agriculture rose by $133.71 \%$ between the five-year periods 1990-1994 and 2010-2014. The increase was 110\% in Brazil, 101.62\% in Ecuador and 93.15\% in Chile, to name just a few.

Argentina, the Bolivarian Republic of Venezuela, Paraguay and Uruguay are exceptions to the continuing downward trend in the agriculture sector's share of GDP over time. In these countries, although the GDP share of agriculture declined between 1990 and 1999, that trend was reversed in the 2000s. The agricultural commodity price boom in 2002-2007 was probably partly responsible for this turnaround. However, as with the Bolivarian Republic of Venezuela and oil, this situation may indicate how heavily these countries depend on agricultural exports (with the exception of the Bolivarian Republic of Venezuela).

The information provided by the series allows the countries to be classified into three different groups, the first of which comprises Argentina, Brazil, Paraguay and Uruguay. The GDP share of agriculture increased in all these countries except Brazil between 1990-1994 and 2010-2014. Nonetheless, agriculture's share of GVA remains higher in Brazil than in any of the other countries analysed. The second group comprises the Bolivarian Republic of Venezuela, Chile, Colombia, Ecuador, Peru and the Plurinational State of Bolivia. Agriculture's share of GDP declined in this group during the 2000s. Even so, the sector's value added also increased in all these countries except the Bolivarian Republic of Venezuela. In the latter, although the size of the agriculture sector as a percentage of GDP declined between 1990 and 2009, it increased slightly from 2010 onward. The third group consists of the Guianas, where the series for the agricultural share of GDP took the form of an inverted $U$ in the 2000s while the GDP share of mining and hydrocarbons increased, as will be seen further on. These three groups of countries are analysed in detail below. 


\section{(a) Argentina, Brazil, Paraguay and Uruguay}

In the case of Argentina, the agriculture sector's share of GDP grew considerably from 2000 onwards (see figure 1). Part of this increase was due to the economic crisis the country faced at the beginning of the twenty-first century (Reca, 2006). Argentina's agriculture sector relied mainly on exports and as a result was little affected by the domestic economic crisis, except during the last few years of Cristina Kirchner's second administration, which sought to ban agricultural exports.

\section{Figure 1}

Argentina: gross domestic product (GDP) shares of the agriculture sector and the mining and oil sector and agricultural value added, 1960-2014

(Percentages and millions of 2005 dollars)

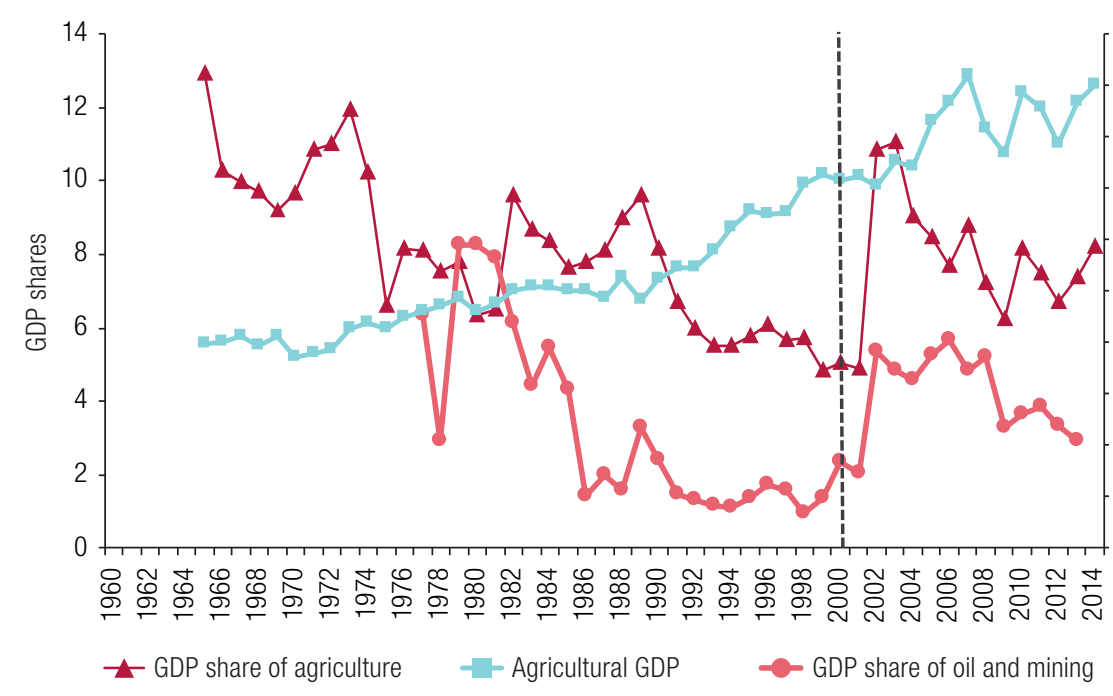

Source: Prepared by the authors, on the basis of data from World Bank, "World Development Indicators (WDI)" (n/d) [online database] http://databank.worldbank.org/data/reports.aspx?source=world-development-indicators.

What is most striking in figure 1 is the upward trend of Argentina's agricultural GDP at factor cost (or GVA). At 2005 prices, its monetary value increased from about US\$ 14 billion in 2010 to about US\$ 18 billion in 2014. Moreover, Argentina's agriculture sector has modernized considerably since the 1990s, generating economies of scale thanks to the opening up of the economy and the comparative advantages of its agriculture (Lema, 1999). Although the combined share of mining and hydrocarbon production in Argentina's GDP has increased in the twenty-first century, it is still lower than that of the agriculture sector.

Figure 2 shows the substantial increase in Brazil's agricultural GVA since the 1960s. This growth has been mainly due to productivity improvements in relation to land availability and the increase in the area given over to agriculture, especially in regions such as the centre-west and north of Brazil and, recently, the region known as MATOPIBA, formed by the states of Maranhão, Tocantins, Piauí and Bahia (Bacha and Carvalho, 2014). However, the share of agriculture in Brazil's GDP declined from about 20\% in 1960 to $5 \%$ in 2014. During the commodity price boom, this figure exceeded $7 \%$ (as in 2003). Between 2007 and 2014, following the price crisis caused by the appreciation of the Brazilian currency in 2005 and 2006 especially, the GDP share of Brazil's agriculture sector ranged from $5 \%$ to $6 \%$. 
Figure 2

Brazil: gross domestic product (GDP) shares of the agriculture sector and the mining and oil sector and agricultural value added, 1960-2014

(Percentages and millions of 2005 dollars)

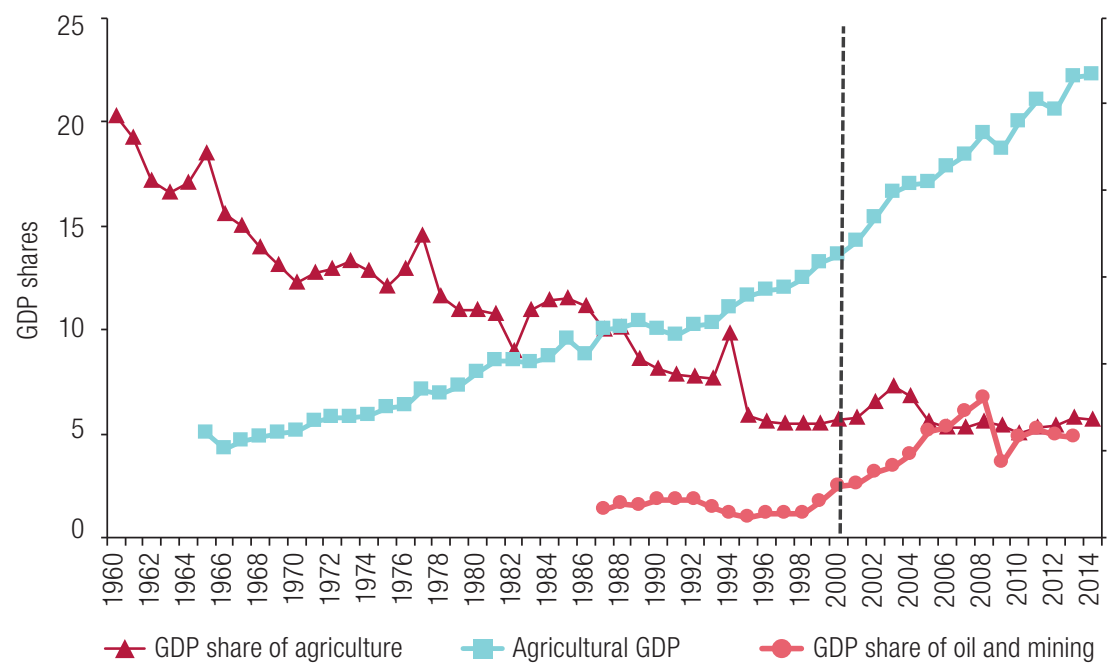

Source: Prepared by the authors, on the basis of data from World Bank, "World Development Indicators (WDI)" (n/d) [online database] http://databank. worldbank.org/data/reports.aspx?source=world-development-indicators.

According to figures 1 and 2, the share of GDP represented by mining and hydrocarbon revenues increased in both Argentina and Brazil in the first 14 years of the twenty-first century. These two nations are known to be very diverse in terms of climate and geological formations, which creates the conditions for large-scale agriculture and provides comparative advantages both in agriculture and in mining and hydrocarbon production.

Although Paraguay and Uruguay do not have large expanses of land, both devote a large part of their territory to agriculture (see table 1). The GDP share of mining and hydrocarbon revenues is practically zero in both Paraguay and Uruguay (see figures 3 and 4).

\section{Figure 3}

Paraguay: gross domestic product (GDP) shares of the agriculture sector and the mining and oil sector and agricultural value added, 1960-2014

(Percentages and millions of 2005 dollars)

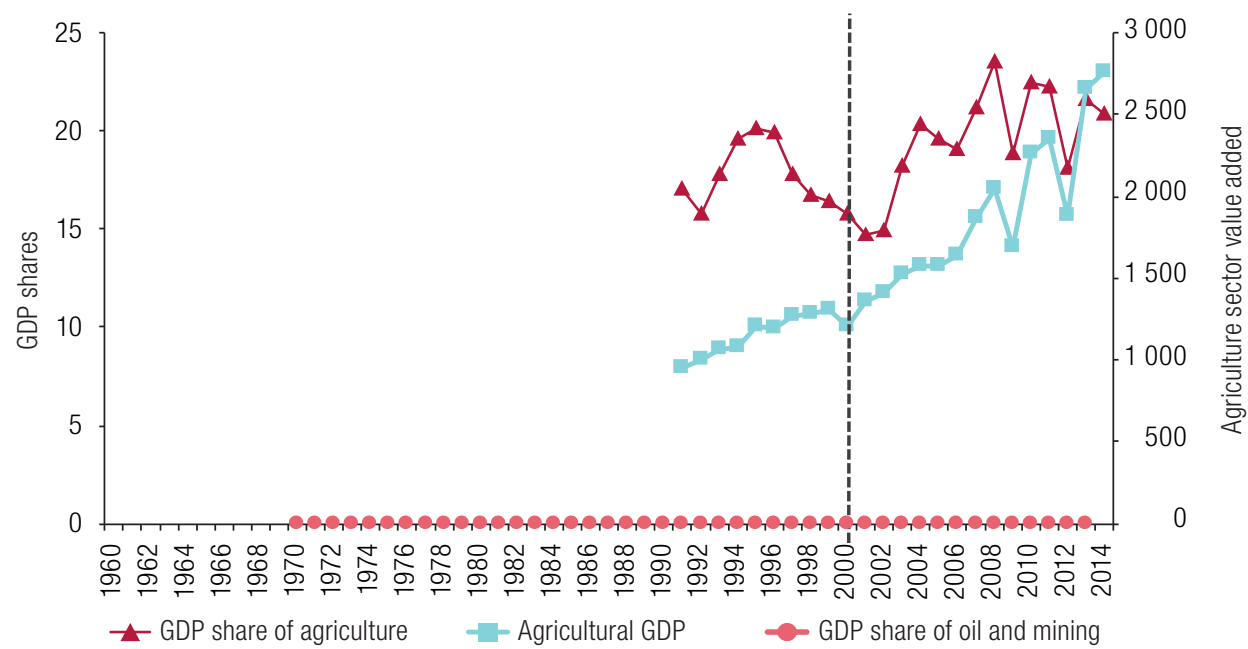

Source: Prepared by the authors, on the basis of data from World Bank, "World Development Indicators (WDI)" (n/d) [online database] http://databank. worldbank.org/data/reports.aspx?source=world-development-indicators. 
Figure 4

Uruguay: gross domestic product (GDP) shares of the agriculture sector and the mining and oil sector and agricultural value added, 1960-2014

(Percentages and millions of 2005 dollars)

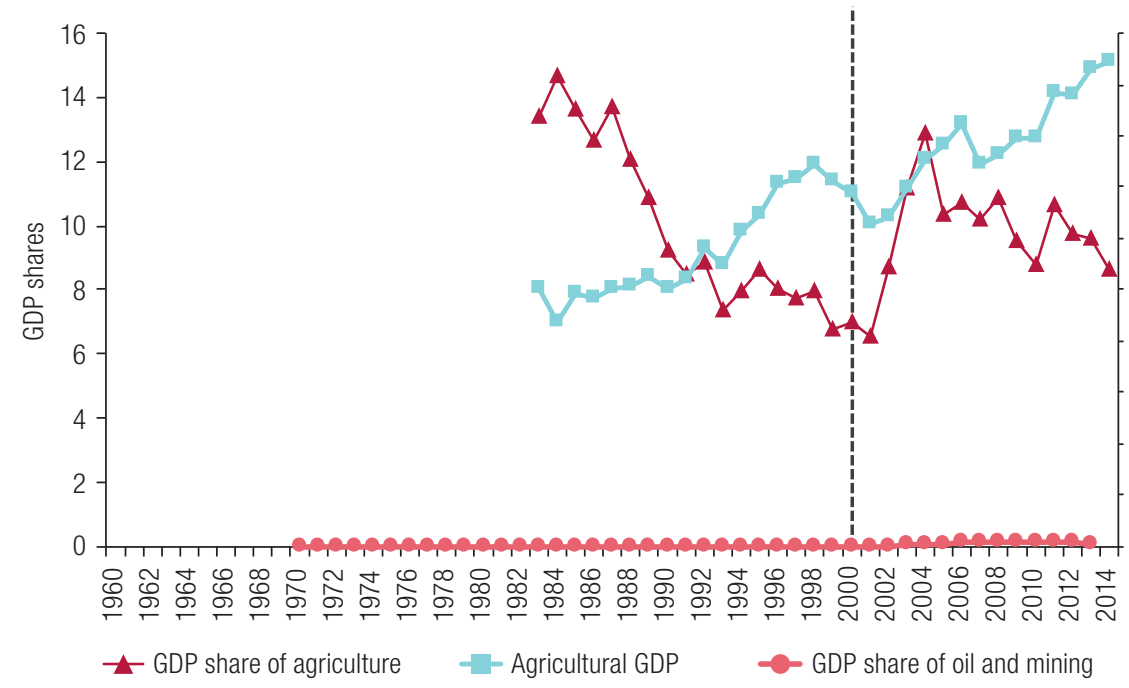

Source: Prepared by the authors, on the basis of data from World Bank, "World Development Indicators (WDI)" (n/d) [online database] http://databank.worldbank.org/data/reports. aspx?source=world-development-indicators.

The GDP share of agriculture in Uruguay was 7\% in 2000, increasing to 8.6\% in 2014 (see figure 4). In Paraguay, these figures were about $15 \%$ and $21 \%$, respectively (see figure 3 ). As can be seen in table 4, the agricultural commodity price boom between 2002 and 2007 allowed Uruguay to double the annual value of its agricultural production between the periods 2000-2004 and 2010-2013. In the case of Paraguay, the increase was almost 90\%.

The four countries mentioned above are all part of MERCOSUR. Throughout the first decade of this century, about $50 \%$ of all Paraguayan exports went to the member countries of that bloc. In Uruguay, the share was some 30\% during the same period (Graf and Azevedo, 2013). It can be concluded that agriculture plays an important role in the economies of these four countries, especially in income generation and in the supply of agricultural products to many other countries.

\section{(b) The Plurinational State of Bolivia, Chile, Ecuador, Peru, Colombia and the Bolivarian Republic of Venezuela}

The GDP share of agriculture has declined steadily in this group of countries since the 1960s, falling even in the agricultural commodity price boom years from 2002 to 2007 (except in the Bolivarian Republic of Venezuela). Even so, the sector's gross value added has grown.

In the case of the Plurinational State of Bolivia (see figure 5), although the inflation-adjusted value of agricultural GDP has been on an upward trend since 1970, the GDP share of agriculture declined during the period of rising agricultural prices (2002 to 2007), while that of the mining and hydrocarbons sector increased. 
Figure 5

Plurinational State of Bolivia: gross domestic product (GDP) shares of the agriculture sector and the mining and oil sector and agricultural value added, 1960-2014

(Percentages and millions of 2005 dollars)

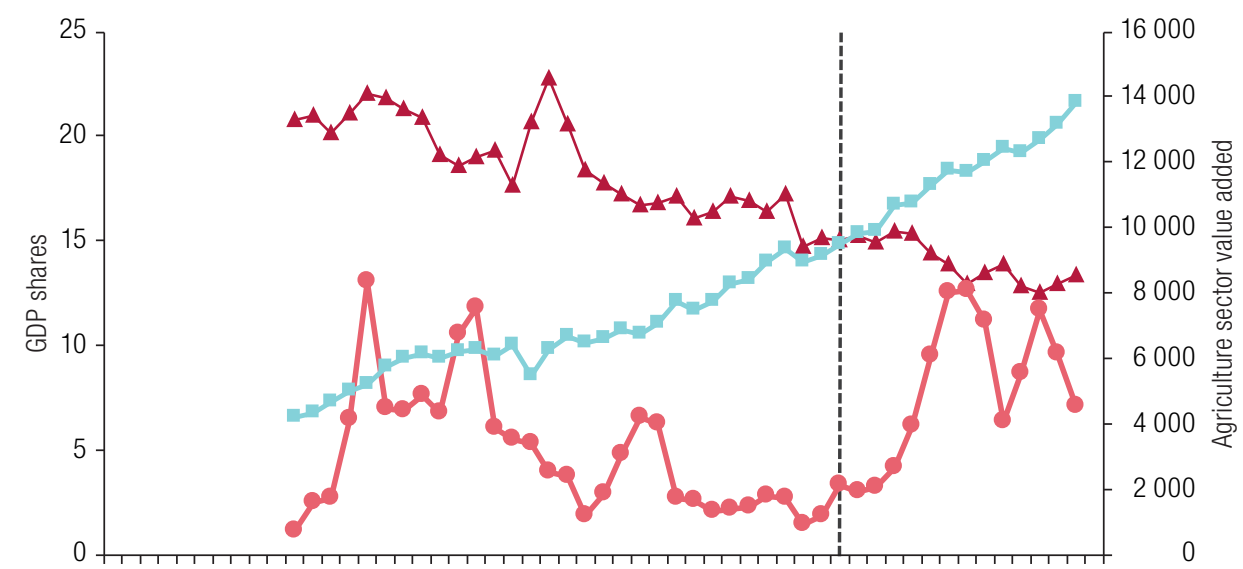

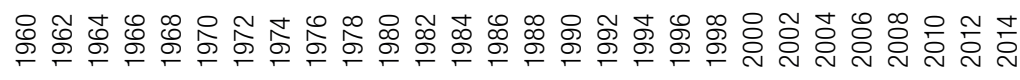

$\leftarrow$ GDP share of agriculture $\quad-$ Agricultural GDP $\quad \longrightarrow$ GDP share of oil and mining

Source: Prepared by the authors, on the basis of data from World Bank, "World Development Indicators (WDI)" (n/d) [online database] http://databank.worldbank.org/data/reports.aspx?source=world-development-indicators.

The situation in Chile (see figure 6) is not very different from that in the Plurinational State of Bolivia. In contrast to countries such as Brazil, Chile's cool climate precludes the cultivation of tropical products. In the twenty-first century, the GDP share of the mining and hydrocarbons sector in Chile has increased even as that of agriculture has declined. In 2014, the mining and hydrocarbons sector in Chile generated three times the GVA of agriculture.

Figure 6

Chile: gross domestic product (GDP) shares of the agriculture sector and the mining and oil sector and agricultural value added, 1960-2014

(Percentages and millions of 2005 dollars)

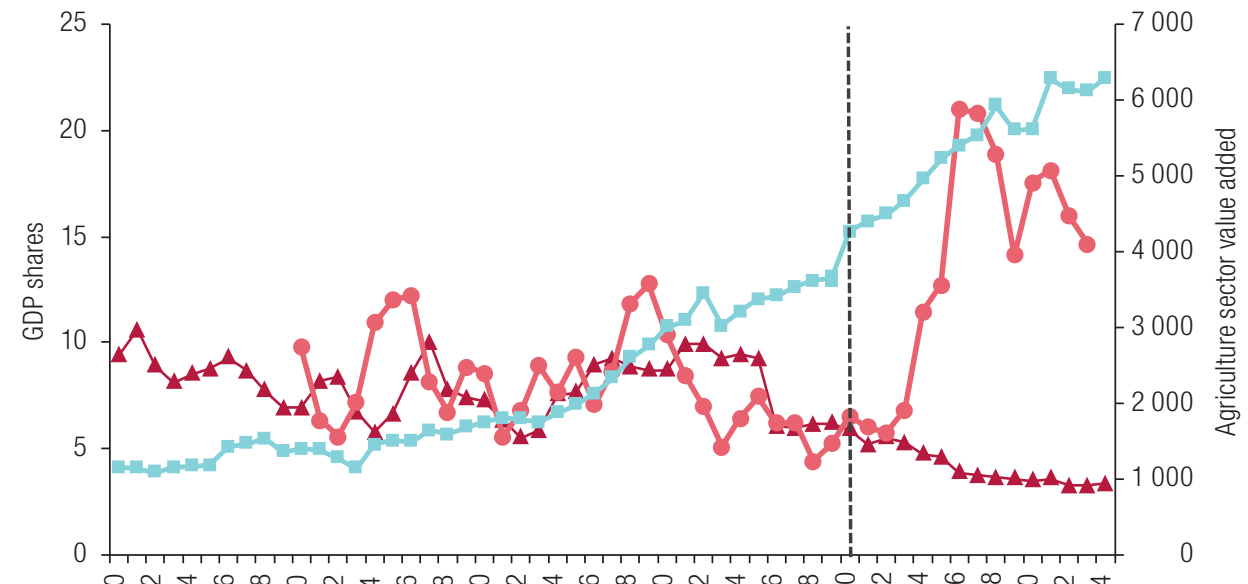

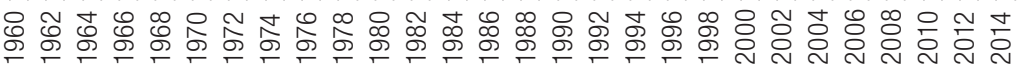

$\leftarrow$ GDP share of agriculture $\quad-$ Agricultural GDP GDP share of oil and mining

Source: Prepared by the authors, on the basis of data from World Bank, "World Development Indicators (WDI)" (n/d) [online database] http://databank.worldbank.org/data/reports.aspx?source=world-development-indicators. 
In Ecuador (see figure 7), the agricultural sector's contribution to GDP declined greatly between 1960 and 2014 despite a considerable increase in the value of production. According to Mateo and García (2014) and Tandazo (2012), the GDP share of mining and hydrocarbons in Ecuador is high, and the importance of this sector is confirmed by the large increase in its share of GDP, which reached 25\% in 2008 before dropping back to 20\% in 2012.

\section{Figure 7}

Ecuador: gross domestic product (GDP) shares of the agriculture sector and the mining and oil sector and agricultural value added, 1960-2014

(Percentages and millions of 2005 dollars)

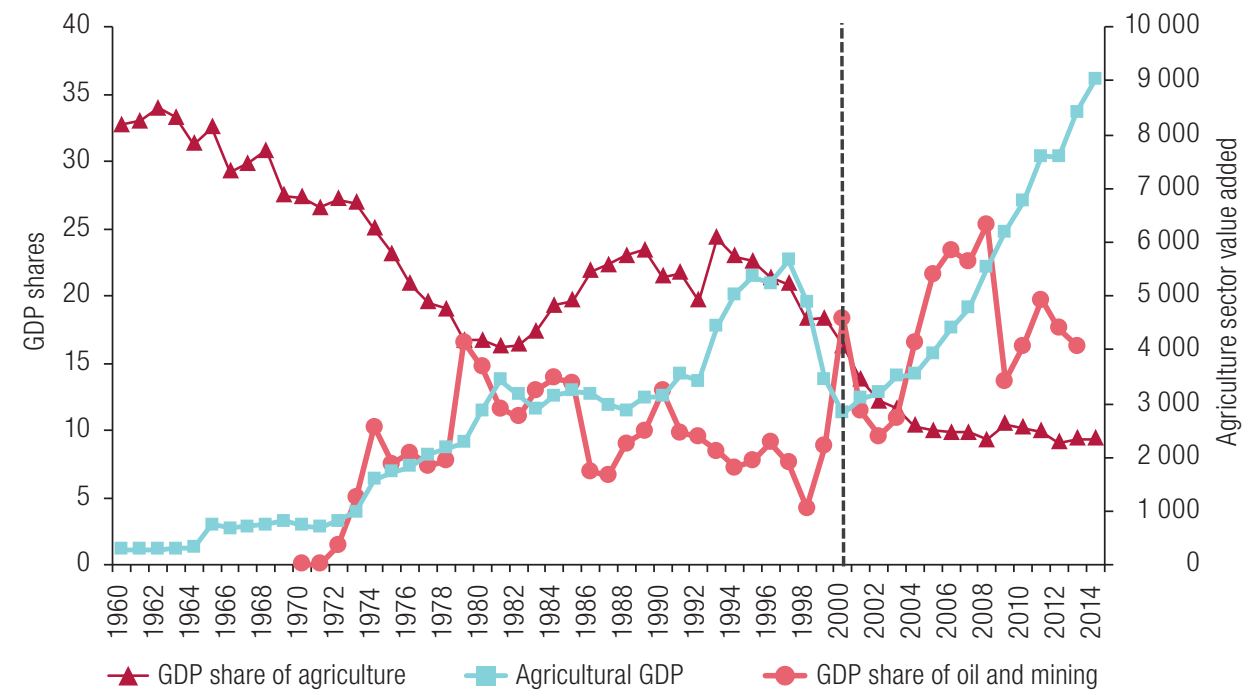

Source: Prepared by the authors, on the basis of data from World Bank, "World Development Indicators (WDI)" (n/d) [online database] http://databank. worldbank.org/data/reports.aspx?source=world-development-indicators.

According to a study by FAO/CAF (2006), Peru is also characterized by the low profitability of its agriculture sector. The leading land use in Peru is for mining, especially silver and copper mining (Dammert and Molinelli, 2007). Figure 8 shows that, at just over 5\%, the GDP share of agriculture in Peru in 2012 was extremely low compared to earlier figures in the data series. In contrast, the share of mining and hydrocarbon revenues in Peru's GDP more than tripled during the agricultural price boom between 2002 and 2007, from about $1.3 \%$ to about $8 \%$.

The data presented in figure 9 show that agricultural value added in Colombia has been unchanged in recent years from the values observed in the early 1990s. In addition, while the GDP share of the agriculture sector in Colombia has declined, the share of mining and hydrocarbons has increased. It seems, then, that Colombia has been developing its mining sector as well this century. According to Muñoz (2014), the Colombian government has adopted policies to attract foreign direct investment into the mining sector since the late 1990s. 
Figure 8

Peru: gross domestic product (GDP) shares of the agriculture sector and the mining and oil sector and agricultural value added, 1960-2014

(Percentages and millions of 2005 dollars)

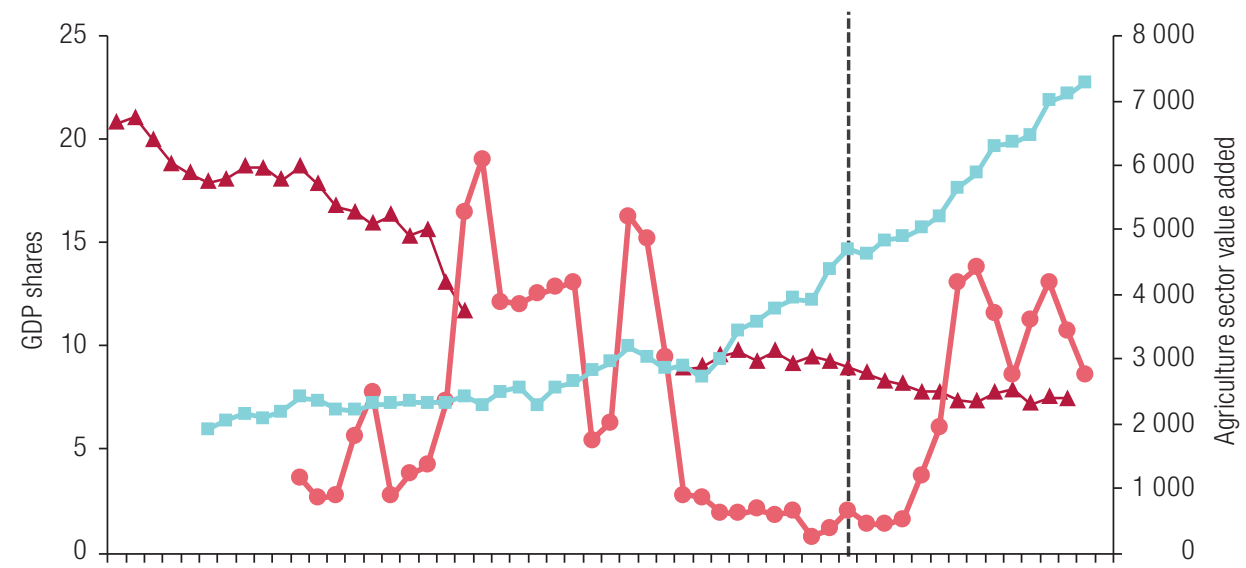

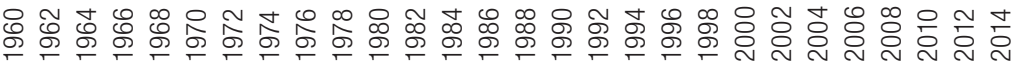

$\neg$ GDP share of agriculture $\quad-$ Agricultural GDP GDP share of oil and mining

Source: Prepared by the authors, on the basis of data from World Bank, "World Development Indicators (WDI)" (n/d) [online database] http://databank.worldbank.org/data/reports.aspx?source=world-development-indicators.

Figure 9

Colombia: gross domestic product (GDP) shares of the agriculture sector and the mining and oil sector and agricultural value added, 1960-2014

(Percentages and millions of 2005 dollars)

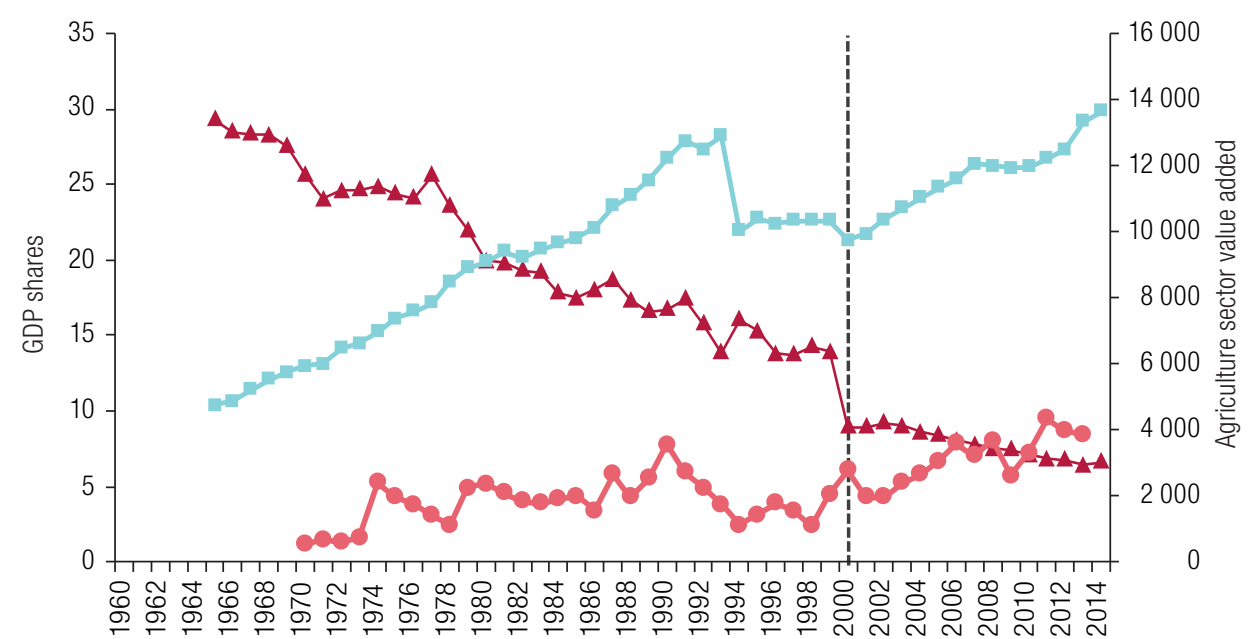

$\_$GDP share of agriculture $\quad-$ Agricultural GDP $\quad-$ GDP share of oil and mining

Source: Prepared by the authors, on the basis of data from World Bank, "World Development Indicators (WDI)" (n/d) [online database] http://databank. worldbank.org/data/reports.aspx?source=world-development-indicators.

The Bolivarian Republic of Venezuela is characterized by large-scale oil production and export, this having been an important sector of its economy since the 1920s (Souza, 2008). Value added in agriculture is low, and its share of Venezuelan GDP is therefore also small, at around 5\% throughout the period under consideration (see figure 10). On the other hand, revenues from oil production and 
mining fluctuated around 30\% of Venezuelan GDP in the period from 1970 to 2013. The Venezuelan economy has suffered from swings in the price of a barrel of oil (Bresser-Pereira, 2008), but the political crisis affecting Maduro's government means that more recent data are not available.

Figure 10

Bolivarian Republic of Venezuela: gross domestic product (GDP) shares of the agriculture sector and the mining and oil sector and agricultural value added, 1960-2014

(Percentages and millions of 2005 dollars)

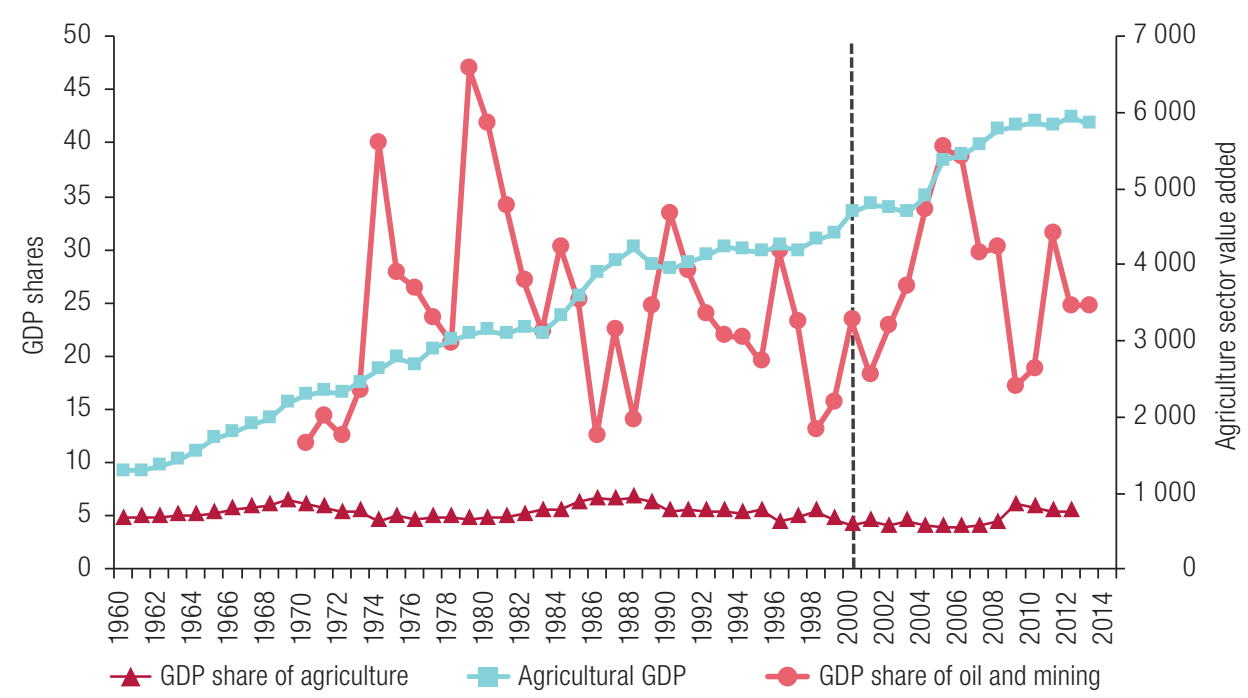

Source:Prepared by the authors, on the basis of data from World Bank, "World Development Indicators (WDI)" (n/d) [online database] http://databank.worldbank.org/data/reports.aspx?source=world-development-indicators.

\section{(c) Guyana and Suriname}

Figures 11 and 12 show the GDP shares of the agriculture sector and the mining and hydrocarbons sector in Guyana and Suriname, respectively. The percentage of GDP represented by agriculture is higher in Guyana than in Suriname. Although the GDP share of agriculture in Guyana increased between 1970 and 1995, this trend has gradually weakened since 1996. The same has happened in Suriname, where the increase was substantial only until 1993, after which the representativeness of agriculture began to decline. The historical series for the GDP share of agriculture in Guyana and Suriname clearly takes the form of an inverted $U$.

In any event, the GDP share of agriculture in both countries was lower in 2014 than in 1960. In addition, the declining trend in the GDP share of agriculture since the mid-1990s was followed by an increase in the share of mining and hydrocarbons.

Because agriculture occupies less than $10 \%$ of Guyana's territory and less than $1 \%$ of Suriname's (see table 1), suitable land is available to expand it in both countries. However, it may not be easy to initiate such an expansion given the lack of a strong institutional framework to secure the process. These countries have infrastructure deficiencies that need to be addressed. As relatively young republics, it is also important for the two economies to consolidate a hegemonic sector, be it agriculture or something else. As figures 11 and 12 show, the sectors acquiring this hegemony in both countries are mining and agriculture. 
Figure 11

Guyana: gross domestic product (GDP) shares of the agriculture sector and the mining and oil sector and agricultural value added, 1960-2014

(Percentages and millions of 2005 dollars)

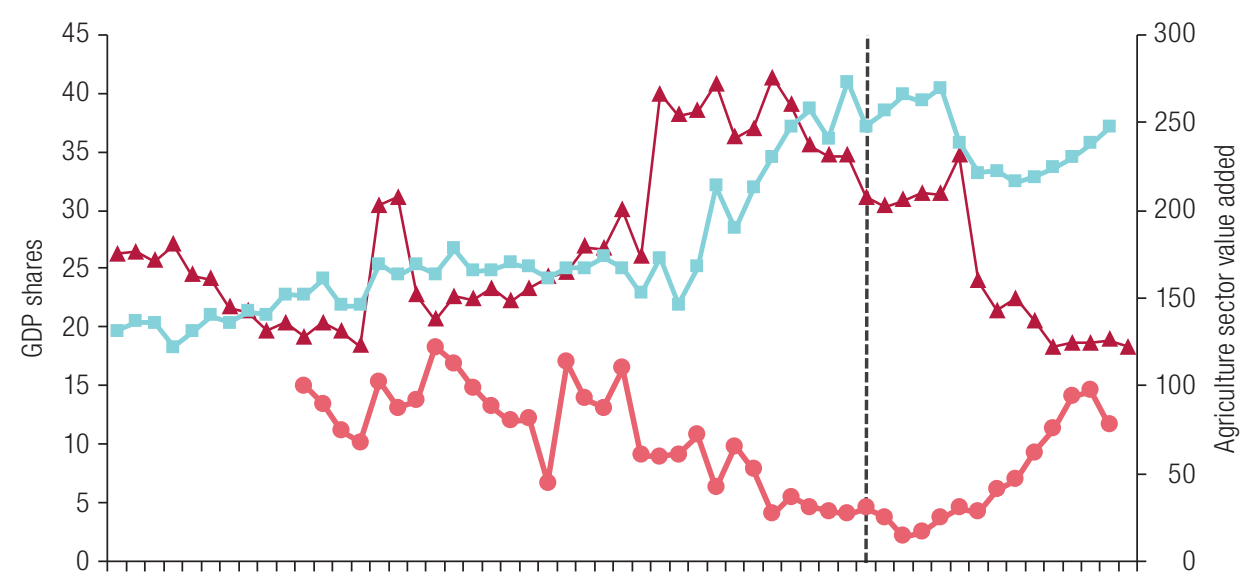

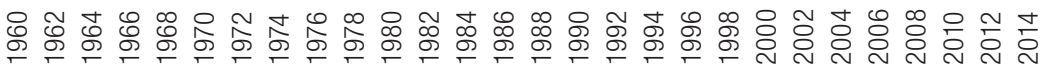

$\leftarrow$ GDP share of agriculture $\quad \longrightarrow$ Agricultural GDP $\quad \longrightarrow$ GDP share of oil and mining

Source: Prepared by the authors, on the basis of data from World Bank, "World Development Indicators (WDI)" (n/d) [online database] http://databank.worldbank.org/data/reports.aspx?source=world-development-indicators.

Figure 12

Suriname: gross domestic product (GDP) shares of the agriculture sector and the mining and oil sector and agricultural value added, 1960-2014

(Percentages and millions of 2005 dollars)

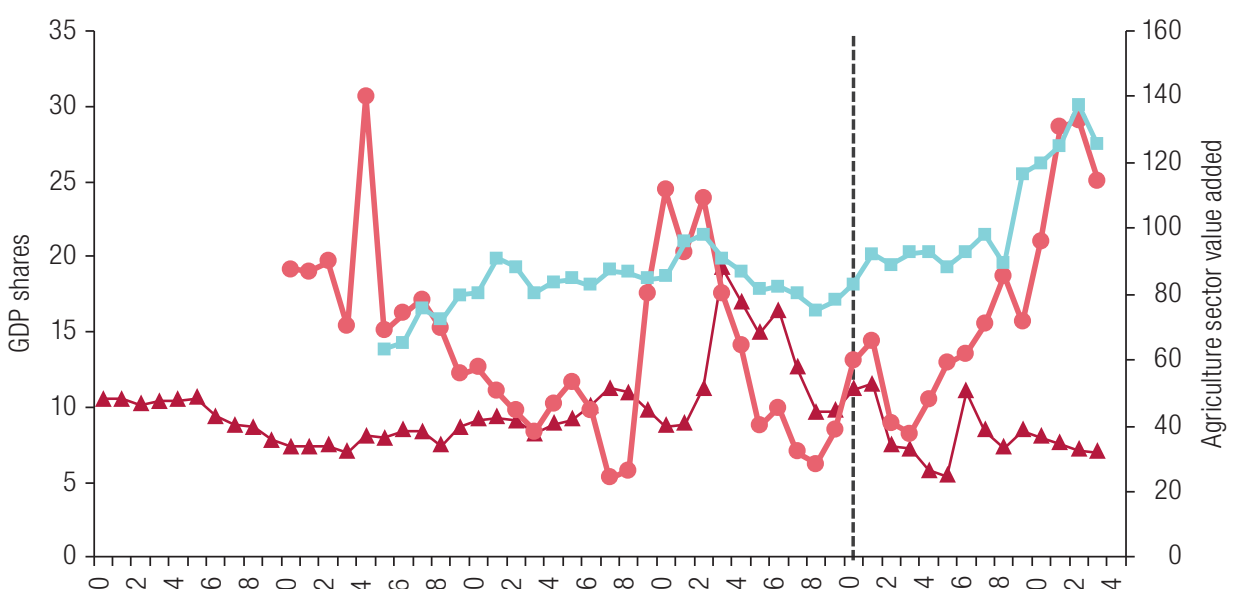

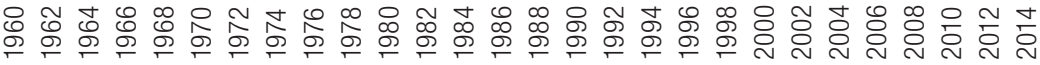

$\rightarrow$ GDP share of agriculture $\quad-$ Agricultural GDP $\quad-$ GDP share of oil and mining

Source: Prepared by the authors, on the basis of data from World Bank, "World Development Indicators (WDI)" (n/d) [online database] http://databank. worldbank.org/data/reports.aspx?source=world-development-indicators. 


\section{Conclusions}

This article has set out to present an overview of the trade-off between agricultural production and mining and hydrocarbon exploitation in the countries of South America. The results of this study indicate that agriculture is, in general, an important sector for the region, even though its share of GDP in the South American countries evinces a constant downward trend. Agricultural production has expanded in most South American countries since 1960, and the region as a whole runs an agricultural and agro-industrial trade surplus. When it comes to the importance of agriculture and of mining and hydrocarbons in each country's GDP, however, patterns are uneven.

Argentina, Brazil, Paraguay and Uruguay are founding members of MERCOSUR and net exporters of agricultural and agro-industrial products. Although the share of mining and hydrocarbons in Brazil's and Argentina's GDP has increased, it remains lower than the share of the agriculture sector. Meanwhile, mining and hydrocarbons do not seem to be important in the GDP of Paraguay and Uruguay. A major feature of all four countries is the good performance of the agriculture sector during the agricultural price boom of 2002 to 2007, reflected in the increase in its contribution to GDP during the period.

The economies of the Bolivarian Republic of Venezuela, Chile, Ecuador, Peru and the Plurinational State of Bolivia are more oriented towards mining and hydrocarbon extraction than agriculture. Their climates and soil partially explain this. Although agricultural production increased in all of them during the period under review, the sector's share of GDP declined throughout, even between 2002 and 2007. On the other hand, the GDP share of mining and hydrocarbons has increased since the 2000s.

Guyana and Suriname are the only countries in which the GDP share of agriculture increased until the mid-1990s, before declining. It is assumed that mining and hydrocarbon extraction will grow faster than agriculture in the two countries despite the availability of land suitable for farming. However, it should be stressed that both of them are taking their first steps in today's globalized world and trying to solve other structural problems in their economies besides that of the production and sale of goods and services.

Soil and climate types and the availability of production factors such as land partially explain the above findings. International investors have been exploiting the potential they represent, and this, as mentioned in the introduction, has given a particular pattern to the international division of labour.

\section{Bibliography}

Acosta, I. (2006), "Balance del modelo agroexportador en América Latina al comenzar el siglo XXl", Mundo Agrario, vol. 7, No. 13, La Plata, National University of La Plata.

Bacha, C. (2012), Economia e política agrícola no Brasil, São Paulo, Atlas.

- (2011), "The evolution of Brazilian agriculture from 1987 to 2009", The Economies of Argentina and Brazil: A Comparative Perspective, W. Baer and D. Fleischer (eds.), Cheltenham, Edward Elgar.

Bacha, C. and L. Carvalho (2014), "What explains the intensification and diversification of Brazil's agricultural production and exports from 1990 to 2012?", IRIBA Working Paper, No. 2, Manchester, International Research Initiative on Brazil and Africa (IRIBA).

Bacha, C. and M. Rocha (1998), "O comportamento da agropecuária brasileira no período de 1987 a 1996", Revista de Economia e Sociologia Rural, vol. 36, No. 1, Brasilia, Brazilian Society of Rural Economics and Sociology (SOBER).

Baer, W. (2008), The Brazilian Economy: Growth and Development, Boulder, Colorado, Lynne Rienner.

Belloni, P. and A. Wainer (2014), "El rol del capital extranjero y su inserción en la América del Sur posneoliberal", Problemas del Desarrollo, vol. 45, No. 177, Mexico City, National Autonomous University of Mexico (UNAM).

Boye, G. and W. Ramautarsing (1997), "Revitalizing agriculture in Suriname", Economic and Sector Study Series, No. 2, Washington, D.C., Inter-American Development Bank (IDB). 
Bresser-Pereira, E. (2008), "O ouro negro: petróleo e suas crises políticas, econômicas, sociais e ambientais na $2^{a}$ metade do século XX", Outros Tempos, vol. 5, No. 6, São Luís, State University of Maranhão.

Bresser-Pereira, L. and N. Marconi (2008), "Existe doença holandesa no Brasil?", paper presented at the Economic Forum of the Getulio Vargas Foundation, São Paulo, March.

Brugnaro, R. and C. Bacha (2009), "Análise da participação da agropecuária no PIB do Brasil de 1986 a 2004”, Estudos Econômicos, vol. 39, No. 1, São Paulo, University of São Paulo.

Cresta, J. and others (2014), "Sector agroindustrial de Paraguay", Nota técnica, No. 734, Washington, D.C., Inter-American Development Bank (IDB).

Dammert, A. and F. Molinelli (2007), Panorama de la minería en el Perú, Lima, Energy and Mining Regulator (OSINERGMIN).

FAO (Food and Agriculture Organization of the United Nations) (n/d), "FAOSTAT" [online database] http:// faostat3.fao.org.

FAO/CAF (Food and Agriculture Organization of the United Nations/Andean Development Corporation) (2006), Perú: nota de análisis sectorial. Agricultura y desarrollo rural, Roma.

Fernández, D., J. Piñeros and D. Estrada (2011), "Financiamiento del sector agropecuario: situación y perspectivas", Temas de Estabilidad Financiera, No. 59, Bogotá, Bank of the Republic of Colombia.

Foster, W. and E. Jara (2005), "Diversificación de exportaciones agrícolas en América Latina y el Caribe: patrones y determinantes", Economía Agraria, vol. 9, Santiago, Agrarian Economist Association.

Furtado, C. (1989), Formação Econômica do Brasil, São Paulo, Companhia Editora Nacional.

Graf, C. and A. Azevedo (2013), "Comércio bilateral entre os países membros do MERCOSUL: uma visão do bloco através do modelo gravitacional", Economia Aplicada, vol. 17, No. 1, São Paulo, University of São Paulo.

Guajardo, B. (2007), "La agenda minera en Chile: revisión y perspectivas", Natural Resources and Development series, No. 120 (LC/L.2674-P), Santiago, Economic Commission for Latin America and the Caribbean (ECLAC).

Ilyásova, M. and I. Sérbinov (2015), "China a la conquista de Latinoamérica", RT - SEPA MÁS [online] https:// actualidad.rt.com/actualidad/192245-china-inversiones-proyectos-america-latina.

INE-Chile (National Statistics Institute of Chile) (2009), Cambios estructurales en la agricultura chilena: análisis intercensal 1976-1997-2007, Santiago.

INE-Uruguay (National Institute of Statistics of Uruguay) (2009), Uruguay en cifras 2009, Montevideo [online] http://www.ine.gub.uy/documents/10181/39317/Uruguay+en+Cifras+09.pdf/13b159a2-19c7-441aa7ce-86260e527747.

Jales, M. (2005), Inserção do Brasil no comércio internacional agrícola e expansão dos fluxos comerciais sul-sul, Institute for International Trade Negotiations (ICONE) [online] http://www.lisina.com.br/upload/ Inser\%C3\%A7\%C3\%A30\%20do\%20Brasil\%20no\%20Com\%C3\%A9rcio\%2OInternacional.pdf.

Lagos, G. and D. Peters (2010), "El sector minero en Sudamérica", Working Paper, No. 10, São Paulo, Plataforma Democrática [online] http://www.plataformademocratica.org/Arquivos/El\%20sector\%20 minero\%20en\%20Sudam\%C3\%A9rica.pdf.

Landa, Y. (2017), "Renta extractiva y la minería del cobre en el Perú", Problemas del Desarrollo, vol. 48, No. 189, Mexico City, National Autonomous University of Mexico (UNAM).

Lema, D. (1999), "El crecimiento de la agricultura argentina: un análisis de productividad y ventajas comparativas", paper presented at the First Interdisciplinary Seminars on Agrarian and Agro-Industrial Studies, School of Economic Sciences, University of Buenos Aires, 6-7 November.

Lence, S. (2010), "The agricultural sector in Argentina: major trends and recent developments", The Shifting Patterns of Agricultural Production and Productivity Worldwide, J. Alston, B. Babcock and P. Pardey (orgs.), Ames, lowa, lowa State University.

Mateo, J. and S. García (2014), "El sector petrolero en Ecuador. 2000-2010", Problemas del Desarrollo, vol. 45, No. 177, Mexico City, National Autonomous University of Mexico (UNAM).

Montenegro, D. and A. Guzmán (1999), "Inversión y productividad en el sector agrícola-agroindustrial boliviano: caso de la agricultura comercial período 1985-1998", Natural Resources and Infrastructure series, No. 43 (LC/L.1288), Santiago, Economic Commission for Latin America and the Caribbean (ECLAC).

Morales, A. (2002), "El sector agrícola y el abastecimiento alimentario en los países exportadores de petróleo: el caso venezolano", Revista Venezolana de Economía y Ciencias Sociales, vol. 8, No. 2, Caracas, Central University of Venezuela. 
Muñoz, E. (2014), "The dark side of the mining 'boom' in Colombia: the open economic mining policies of Colombia's lasts governments have led to internal displacement and harm to the environment by multinational mining companies", master's thesis, Oslo, University of Oslo.

Oyhantçabal, G. and M. Sanguinetti (2017), "El agro en Uruguay: renta del suelo, ingreso laboral y ganancias", Problemas del Desarrollo, vol. 48, No. 189, Mexico City, National Autonomous University of Mexico (UNAM).

Pardey, P., S. Wood and R. Hertford (eds.) (2009), Investigaciones a futuro: proyección del potencial agropecuario en América Latina y el Caribe, Washington, D.C., Inter-American Development Bank (IDB)/ International Food Policy Research Institute (IFPRI).

Puyana, A. and A. Constantino (2013), "Sojización y enfermedad holandesa en Argentina: ¿la maldición verde?", Problemas del Desarrollo, vol. 44, No. 175, Mexico City, National Autonomous University of Mexico (UNAM).

Reca, L. (2006), Aspectos del desarrollo agropecuario argentino, 1875-2005, Buenos Aires, National Academy of Agronomy and Veterinary Science.

Reca, L. and D. Lema (2016), "El consumo de carnes en Argentina 1950-2012", Desarrollo Económico, vol. 56, No. 219, Buenos Aires, Institute of Economic and Social Development (IDES).

Romero, Y. (2011), "Incidencia del PIB agropecuario en el PIB nacional: evolución y transformación”, Revista Gestión \& Desarrollo, vol. 8, No. 2, Bogotá, University San Buenaventura.

Rudas, G. and J. Espitia (2013), "La paradoja de la minería y el desarrollo: análisis departamental y municipal para el caso de Colombia", Minería en Colombia: institucionalidad y territorio, paradojas y conflictos, vol. 2, S. Morelli and L. Garay, Bogotá, Comptroller General of the Republic.

Servín, M. (2011), Desarrollo productivo del Paraguay, Asunción, Centre for Analysis and Diffusion of the Paraguayan Economy (CADEP) [online] https://mega.nz/\#!RKAkkJSa!VogNaAcrQUtX83YC_ joAHjX10NYOCpgmfJKH9xP2OTM.

Silva, J., S. Gómez and R. Castañeda (2012), “'Boom' agrícola e persistência da pobreza na América Latina: algumas reflexões", Revista Nera, vol. 13, No. 16, São Paulo, University of São Paulo.

Souza, R. (2008), "O desenvolvimento econômico da Venezuela, 1950/2006", PhD dissertation, Porto Alegre, Federal University of Rio Grande do Sul.

Staritz, C., J. Gold and R. Atoyan (2007), "Guyana: why has growth stopped? An empirical study on the stagnation of economic growth", IMF Working Papers, No. 86, Washington, D.C., International Monetary Fund (IMF).

Tandazo, T. (2012), La actividad económica del Ecuador: una visión desde la economía espacial. Informe de coyuntura económica, No. 11, Loja, Private Technical University of Loja.

Urioste, G. (2009), El sector agropecuario, La Paz, Unit for Analysis of Social and Economic Policies (UDAPE).

Valdés, A. and W. Foster (2011), "Latin America's 'new open regionalism' and WTO negotiations: the case of agriculture", Economía Agraria y Recursos Naturales, vol. 6, No. 12, Valencia, Spanish Association of Agrarian Economy.

Visentini, P. (2010), "Guiana e Suriname: uma outra América do Sul”, Conjuntura Austral, vol. 1, No. 1, Porto Alegre, Federal University of Rio Grande do Sul.

World Bank (n/d), World Development Indicators (WDI) [online database] http://databank.worldbank.org/ data/reports.aspx?source=world-development-indicators.

Zarrilli, A. (2013), "The La Plata basin: rivers, plains, and societies in the Southern Cone", RCC Perspectives, No. 7, Munich, Rachel Carson Center. 